\title{
Priority contribution
}

\section{The rediscovery of Gurney's Pitta Pitta gurneyi in Myanmar and an estimate of its population size based on remaining forest}

\section{cover}

\author{
JONATHAN C. EAMES, HTIN HLA, PETER LEIMGRUBER, DANIEL \\ S. KELLY, SEIN MYO AUNG, SAW MOSES and U SAW NYUNT TIN
}

\section{Summary}

A preliminary survey for Gurney's Pitta Pitta gurneyi was undertaken at five sites within the species' historical range in the Tanintharyi (Tenasserim) Division of Myanmar from 14 to 24 May 2003. During the surveys, Gurney's Pittas were heard and/or observed at four sites with a maximum of 10-12 pairs recorded at one site. Birds were encountered in logged primary and secondary forest below $100 \mathrm{~m}$ on flat ground, sometimes less than $10 \mathrm{~m}$ from forest edge. All encounters were within $2 \mathrm{~km}$ of the main trans-Tanintharyi highway. Landsat satellite imagery was used to map remaining lowland forests and Gurney's Pitta habitat in the Tanintharyi Division. Our analysis demonstrated that only $4,705 \mathrm{~km}^{2}$ of lowland forest remain with about $3,496 \mathrm{~km}^{2}$ in flat areas with slopes $<10^{\circ}$. On the basis of previously reported population densities, these habitats may support a population of $5,152-8,586$ pairs. Much of the remaining habitat is restricted to small and fragmented patches $<_{1} \mathrm{~km}^{2}$ in area. The five largest patches have a total area of $1,431 \mathrm{~km}^{2}$ and range in size from 137 to $467 \mathrm{~km}^{2}$. This survey demonstrated that Gurney's Pitta still occurs within its historical range in Myanmar, although probably not at any of the historical collecting localities visited. The global population of Gurney's Pitta is at least 1oo\% greater than the latest published estimate. This survey has also shown that the Gurney's Pitta population in southern Tanintharyi Division is under pressure from forest conversion to oil palm. Contrary to the situation in neighbouring Thailand, sufficient forest remains to establish landscape level protected areas covering a broad ecological continuum. Securing populations of Gurney's Pitta within either expanded or entirely new protected areas must be the best chance for the species and the Sundaic flora and fauna of which it is part.

\section{Introduction}

Gurney's Pitta Pitta gurneyi was discovered in Burma (now Myanmar) in 1875 (Hume 1875), and later described from Siam (now Thailand) in 1914 (Gyldenstolpe 1916). The general paucity of knowledge about the species and concern for its global status prompted a thorough review of its habitat, status and distribution by Collar et al. (1986), coinciding with its rediscovery in Thailand (Round and Treesucon 1986). Subsequent research and conservation efforts for the species in Thailand have significantly increased our knowledge of it and it is now the most studied of all pitta species (Gretton et al. 1993, Lambert and Woodcock 1996, BirdLife International 2001). 
Gurney's Pitta is known historically from six sites in southern Myanmar and 21 sites in southern Thailand (BirdLife International 2001). The sites in Myanmar were (from north to south) Lenya, Sungei Baleihgyi, Telok Besar, Maliwun, Bankachon and Kampong Pulo Ton Ton (Figure 1). Specimens from these localities were collected by W. Davison, on behalf of A. O. Hume, and W. L. Abbott for the United States National Museum (USNM) during 1875, 1877 and 1904 (Collar et al. 1986). Davison is credited by Collar et al. (1986) with the collection of the type material, no fewer than 38 specimens deposited in The Natural History Museum U.K., and for providing the foundation of knowledge on the species. For a discussion on the variations in spelling of Burmese places names and their geographical location refer to Collar et al. (1986). In the past, names for collecting localities used in the literature were based on Malay words, reflecting the ethnicity of fishing communities along the southern Tanintharyi

Forest cover, land-use and localities mentioned in the text

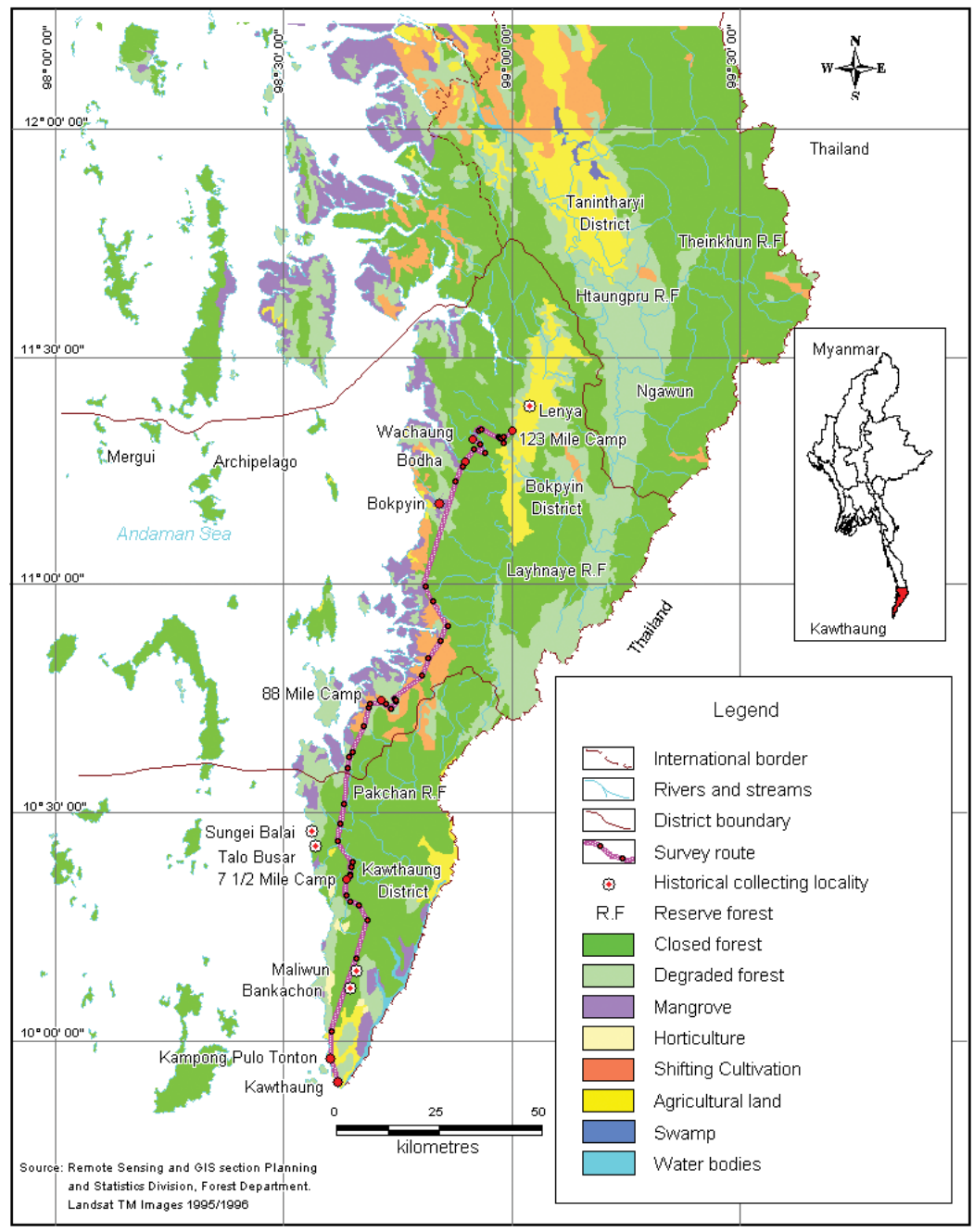

Figure 1. Forest cover, land-use and localities mentioned in the text. 
Table 1. Gurney's Pitta collecting localities in Myanmar.

\begin{tabular}{|c|c|c|c|c|c|}
\hline $\begin{array}{l}\text { Locality } \\
\text { (BirdLife } \\
\text { International } \\
\text { 2001) }\end{array}$ & $\begin{array}{l}\text { Variant spelling } \\
\text { (Collar et al. } \\
\text { 1986) }\end{array}$ & $\begin{array}{l}\text { Current name } \\
\text { in use (this } \\
\text { survey) }\end{array}$ & $\begin{array}{l}\text { Elevation } \\
\text { (m a.s.l.) }\end{array}$ & $\begin{array}{l}\text { Geographical } \\
\text { coordinates } \\
\text { (Collar et al. } \\
\text { 1986) }\end{array}$ & $\begin{array}{l}\text { Geographical } \\
\text { coordinates } \\
\text { (this survey) }\end{array}$ \\
\hline Lenya & Laynah & Lenya & - & $\begin{array}{l}11^{\circ} 28^{\prime} \mathrm{N} \\
99^{\circ} \mathrm{Oo}^{\prime} \mathrm{E}\end{array}$ & - \\
\hline Sungei & Sungei & Chaung Phar & & & \\
\hline Baleihgyi & Balik & Gyi & - & $\begin{array}{l}10^{\circ} 29^{\prime} \mathrm{N} \\
98^{\circ} 32^{\prime} \mathrm{E}\end{array}$ & - \\
\hline Telok Besar & Talobusa & Or Gyi & - & $\begin{array}{l}10^{\circ} 23^{\prime} \mathrm{N} \\
98^{\circ} 33^{\prime} \mathrm{E}\end{array}$ & - \\
\hline Maliwun & Malewoon & Maliwun & 12 & $\begin{array}{l}10^{\circ} 14^{\prime} \mathrm{N} \\
98^{\circ} 37^{\prime} \mathrm{E}\end{array}$ & $\begin{array}{l}10^{\circ} 15^{\prime} 24^{\prime \prime} \mathrm{N} \\
98^{\circ} 35^{\prime} 45^{\prime \prime} \mathrm{E}\end{array}$ \\
\hline Bankachon & Bankasoon & Bankachun & 13 & $\begin{array}{l}10^{\circ} 09^{\prime} \mathrm{N} \\
98^{\circ} 36^{\prime} \mathrm{E}\end{array}$ & $\begin{array}{l}10^{\circ} 08^{\prime} 15^{\prime \prime} \mathrm{N} \\
98^{\circ} 35^{\prime} 38^{\prime \prime} \mathrm{E}\end{array}$ \\
\hline $\begin{array}{l}\text { Kampong } \\
\text { Pulo Tonton }\end{array}$ & Palaw-ton-ton & $\begin{array}{l}\text { Palo or Pulo- } \\
\text { ton-ton }\end{array}$ & 1 & $\begin{array}{l}10^{\circ} \mathrm{OI^{ \prime } \mathrm { N }} \\
98^{\circ} 31^{\prime} \mathrm{E}\end{array}$ & $\begin{array}{l}10^{\circ} \mathrm{OI}^{\prime} 83^{\prime \prime} \mathrm{N} \\
98^{\circ} 3 \mathrm{O}^{\prime} 2.4^{\prime \prime} \mathrm{E}\end{array}$ \\
\hline
\end{tabular}

coast. However, some of these places now have Burmese names (Table 1). Note that an additional place, the confusingly named, Sungeibaleih, lies $6 \mathrm{~km}$ south-west of Chaung Phar Gyi (the former Sungei Baleihgyi). All specimen localities in Myanmar are found within Tanintharyi Division, one of the seven divisions and seven states within the Union of Myanmar. Tanintharyi Division is contained within the administrative unit previously known as Tenasserim. The Tenasserim Range additionally includes the Mon State (although contra Round (1995) Mon State is in north and not south Tenasserim).

Gurney's Pitta is the only bird species endemic to Peninsula Thailand and the Tenasserim Range (Lambert and Woodcock 1996). Its geographical range has been variously defined as $7^{\circ} 25^{\prime} \mathrm{N}$ to $11^{\circ} 50^{\prime} \mathrm{N}$ (Lambert and Woodcock 1996) and $7^{\circ} \mathrm{N}$ to $12^{\circ} \mathrm{N}$ (BirdLife International 2001). The species is restricted to semi-evergreen rainforest (the so-called Thai type) and appears to be associated with secondary, regenerating forest. Its occurrence seems to be associated with streams and gullies and the presence of spiny palms over $1 \mathrm{~m}$ tall, in which it nests (BirdLife International 2001). The altitudinal limits of the species have been defined by the presence of territories at Khao Pra-Bang Khram, Thailand between 80 and $140 \mathrm{~m}$ a.s.l., with most below $100 \mathrm{~m}$ a.s.l. (BirdLife International 2001). Lambert and Woodcock (1996) reported that all records of the species since 1986 have been below $160 \mathrm{~m}$ a.s.l. Records of the species at altitudes of 610-1,070 $\mathrm{m}$ a.s.l. have now been discredited (Round 1995), although there is a credible report of a territory at $250 \mathrm{~m}$ a.s.l. (BirdLife International 2001).

Widespread loss of lowland forest in southern Thailand and its conversion to crops, particularly oil palm and rubber, is widely acknowledged as the principal reason for the species' decline (Collar et al. 1986, Lambert and Woodcock 1996, BirdLife International 2001). Prior to our survey the only known population, believed to be II pairs, was in and around the Khao Pra-Bang Khram Wildlife Sanctuary in Trang province, Thailand. The species is currently classified by IUCN as Critically Endangered and has been described as "only just surviving and on the verge of extinction" and "one of the lowest known populations of bird (or any animal species) on the planet" (BirdLife International 2001, p. 1,895). Khao Pra-Bang Khram Wildlife 
Sanctuary has been the focus of a number of well-documented conservation initiatives which have failed to secure the conservation of the last known population of the species within the protected area (BirdLife International 2001). The failure to stem forest clearance through adequate law enforcement, combined with the belief that no other viable populations remain in Thailand, provided only a bleak outlook for Gurney's Pitta conservation in Thailand. Therefore, the current distribution and status of the species in Myanmar needed to be clarified urgently (BirdLife International 2001). We report on a survey undertaken by the Biodiversity and Nature Conservation Association (BANCA) and BirdLife International in May 2003 within the historical range of the species in Myanmar. We also present the results of a satellite mapping analysis to determine the extent of remaining forest habitats in southern Tanintharyi Division. The results of the fieldwork and mapping analyses provide new information on the species' conservation status and can be used to guide conservation recommendations. The results of the survey and forest mapping exercises are then used to make a tentative population estimate for Myanmar. We also report on the state of the forest.

\section{Methods}

\section{Gurney's Pitta surveys}

Based on previous recommendations, surveys for the species should coincide with the predicted March-June peak in calling activity (Gretton et al. 1993, Round 1995). The survey began on 4 May 2003 with a series of visits to historical collecting localities. Additional, new survey sites were selected based on the occurrence of known Gurney's Pitta habitat determined from recent Landsat satellite images, vegetation maps and 1:50,000 topographical maps. New survey sites were constrained to be in closed-canopy lowland forest at an elevation of $<160 \mathrm{~m}$ a.s.l., and either flat or with slopes $<10^{\circ}$. Given the limited duration of the survey and its preliminary nature, we also selected sites based on their accessibility (i.e. within $2 \mathrm{~km}$ of a drivable road).

Field surveys of five previously unexplored forest sites were undertaken in Tanintharyi Division between 14 and 24 May 2003. The field team searched for pittas on foot following existing trails and logging tracks, navigating through the forest using a compass bearing or the knowledge of local guides. Transects were walked slowly (c. 1-2 km/h). Prerecorded "lilip" and "skew" calls were broadcast regularly at stations, spaced at approximately $100 \mathrm{~m}$ intervals along the survey route. The tapes had been copied previously from recordings made in Thailand and were replayed using a Marantz $\mathrm{CP}_{43} 3$ and a Sanyo TRC 1146 cassette tape-recorder fitted with external loudspeakers. Both calls were played at each station. The number of times any call was played at one station, and the length of time spent awaiting a response at any given station, varied from 5 to $30 \mathrm{~min}$. The type and number of calls were noted. The sex of the responding bird was recorded by direct observation whenever possible. The geographic coordinates for each location were documented using hand-held Global Positioning System (GPS). Other ecological parameters including altitude (using GPS and hand-held altimeters) and topography (using a compass and by reference to 1:50,000 topographical maps) were also noted. Broad habitat type, forest architecture and components of the understorey were noted but not recorded quantitatively. All bird and mammal species observed and heard were also recorded. 
Particular emphasis was placed on recording Globally Threatened and Globally Near Threatened bird species (as defined by BirdLife International 2001). These data will be presented elsewhere. Human activity and impact was also noted. Surveys were carried out from o6hoo until the rain became too frequent or heavy to continue. Heavy and continuous rain forced termination of the survey on 24 May.

\section{Satellite mapping of remaining Gurney's Pitta habitat}

Landsat Thematic Mapper (TM) and Enhanced Thematic Mapper (ETM+) satellite data were used to delineate remaining forest cover and changes in forest cover in the southern Tanintharyi Division of Myanmar between 1990 and 2000. Satellite images from both Landsat sensors were combined in remote sensing analysis to determine spectral changes in land cover characteristics that are associated with changes in forest cover. Once these changes were identified and spectral signatures for the forest cover and the forest cover change class had been derived, we used supervised classification procedures to produce an intermediate map. This intermediate map provided accurate delineation of current forest cover, as of 2000 , and past forest cover as of 1990. Additional details on the techniques used for the forest cover and forest cover change mapping are provided elsewhere (Leimgruber et al. 2003).

To distinguish lowland forests from other upland forest types in the intermediate map, we used digital elevation data acquired during the Shuttle Radar Topographic Mission (SRTM; Farr and Kobrick 200o). Collected using two side-looking synthetic aperture radar instruments and radar interferometry, the SRTM imagery provided elevation data with a spatial resolution of roughly $90 \mathrm{~m}$. These data are available at http://edcsgs9.cr.usgs.gov/pub/data/srtm/Eurasia/. We combined the elevation data with the forest cover map to identify all lowland forest $<160 \mathrm{~m}$ a.s.l. with a slope $<10^{\circ}$. To exclude mangrove forests from the lowland forest map, we used on-screen digitizing techniques to delineate mangrove areas that could visually be identified on the satellite imagery. A Geographic Information System (GIS) was used to determine the extent of the remaining lowland forests, the percentage of these forests lost during the 1990-2000 decade, and to calculate patch sizes for the remaining forest fragments.

\section{Results}

\section{Historical collecting localities}

We visited four of the six historical sites for Gurney's Pitta in Myanmar (Table 1). The only historical collecting localities not visited were Lenya and Sungeibaleihgyi. We conducted surveys at four locations within $20 \mathrm{~km}$ of Lenya and found the species at all of these sites. On 9 May we visited Pulo Ton-Ton Island where we found no evidence of the presence of Gurney's Pitta (Table I). All natural forest in the area appeared to have been converted to cashew, betel nut and coconut plantations. There was a large human settlement on the east side of the island and on the west side a derelict ice factory. On 4 May we visited Maliwun and Bankachun (Table 1). Both settlements are on the trans-Tanintharyi highway, with Bankachun $22 \mathrm{~km}$ north and Maliwun $32 \mathrm{~km}$ north of Kawthaung (the largest town in southern Tanintharyi). These two villages are now almost contiguous with one another. Bankachun is only separated from the expanding Kawthaung by a series of orchards. All lowland forest in 
the vicinity of these villages appears to have undergone conversion to oil and coconut palm, betel and cashew nut and rubber plantations. Heavily logged forest remained on the hills visible on the west side of the highway. During interviews U Aye Thaung, the headman of Maliwun, recalled that Gurney's Pitta previously occurred in the area, but said it was now only found in remote areas. On 11 May we visited Talobusa which is now called Or Gyi in Burmese, meaning big bay. All primary forest around this village had been replaced by perennial crops including coconut palms, betel and cashew nut. A $2-\mathrm{km}$ wide strip of forest separated this village from the clearing made by the Yuzana Corporation, which will be converted to oil palm at some future point. Interviews did not yield any information on Gurney's Pitta from this site. The Burmese name Chaung Phar Gyi, meaning origin of a big river, replaces the Malay name of Sungeibaleihgyi for this large multi-ethnic village. The forest edge of a Yuzana oil palm plantation was only $2.5 \mathrm{~km}$ from the village.

\section{New survey sites}

In total we surveyed five new forest sites south of $12^{\circ} \mathrm{N}$, within the historical range of the species, and we found Gurney's Pitta at four sites (Figures 1, 2). Details of the sites and all Gurney's Pitta contacts, were as follows (Table 2, Appendix):

Site 1: Seven and a half Mile Camp, Yuzana Plantation \# $1\left(10^{\circ} 26^{\prime} 25 \cdot 5^{\prime \prime} \mathrm{N}\right.$ $\left.98^{\circ} 34^{\prime} 59 \cdot 5^{\prime \prime}\right)$

This site was surveyed on the afternoon of 14 May and the morning of 15 May. Four transects were completed. Transect A $\left({ }^{\circ} 0^{\circ} 26^{\prime} 25.6^{\prime \prime} \mathrm{N} 98^{\circ} 34^{\prime} 59 \cdot 5^{\prime \prime}\right)$ was surveyed by J.C.E., S.M.A. and S.M. during the afternoon of 14 May until dusk, consisted of logged forest edge on hill-slopes $>10^{\circ}$, and an abandoned undulating logging road through logged forest. The weather was overcast and humid but without rain. No Gurney's Pittas were recorded. Transect B ( $\left.10^{\circ} 27^{\prime} 28.9^{\prime \prime} \mathrm{N} 98^{\circ} 35^{\prime} \mathrm{O} 8.3^{\prime \prime} \mathrm{E}\right)$ was surveyed from $c$. o7hoo to 14 hoo on 15 May by J.C.E. and S.M.A. The transect supported logged primary forest in a $100 \mathrm{~m}$ wide strip sandwiched between an oil-palm clearing and primary forest on hill-slopes. Transects C $\left(10^{\circ} 27^{\prime} 33.9^{\prime \prime} \mathrm{N} 98^{\circ} 36^{\prime}\right.$ oo. $\left.1^{\prime \prime} \mathrm{E}\right)$ and $\mathrm{D}\left(10^{\circ} 27^{\prime} 21.5^{\prime \prime} \mathrm{N} 98^{\circ} 34^{\prime} 39.5^{\prime \prime} \mathrm{E}\right)$ supporting logged primary forest on hill-slopes were also surveyed during 15 May by H.H., S.M.A. and S.M. There were heavy pre-dawn showers and very heavy rain at $c$. Iohoo for $30 \mathrm{~min}$, with heavy showers again in the afternoon. No Gurney's Pittas were recorded on any transect.

Site 2: 88 Mile Camp, Yuzana Plantation \# 3 ( (O $\left.^{\circ} 49^{\prime} \mathrm{O}^{\prime \prime} \mathrm{N} 98^{\circ} 39^{\prime} 79^{\prime \prime} \mathrm{E}\right)$

This site was surveyed from 17 to 20 May. Four transects were completed.

Transect A: At c. o7hoo J.C.E., S.M.A., S.M. and a local guide, entered forest at $10^{\circ} 49^{\prime} 21.9^{\prime \prime} \mathrm{N} 98^{\circ} 40^{\prime} 58.4^{\prime \prime} \mathrm{E}$ and walked south-east all morning, covering perhaps no more than $3 \mathrm{~km}$, then headed north-east and then south-west before exiting the forest at $16 \mathrm{~h}_{30}$ at $10^{\circ} 49^{\prime} 13.1^{\prime \prime} \mathrm{N} 98^{\circ} 40^{\prime} 59 \cdot I^{\prime \prime} \mathrm{E}$. The site consisted of a flatbottomed valley perhaps $400 \mathrm{~m}$ wide between low-lying hills (Figure 3). Canopy height was estimated to be in the range $30-35 \mathrm{~m}$, with emergent trees reaching $40 \mathrm{~m}$. The canopy cover was estimated to be $>80 \%$. Buttressing was common in 


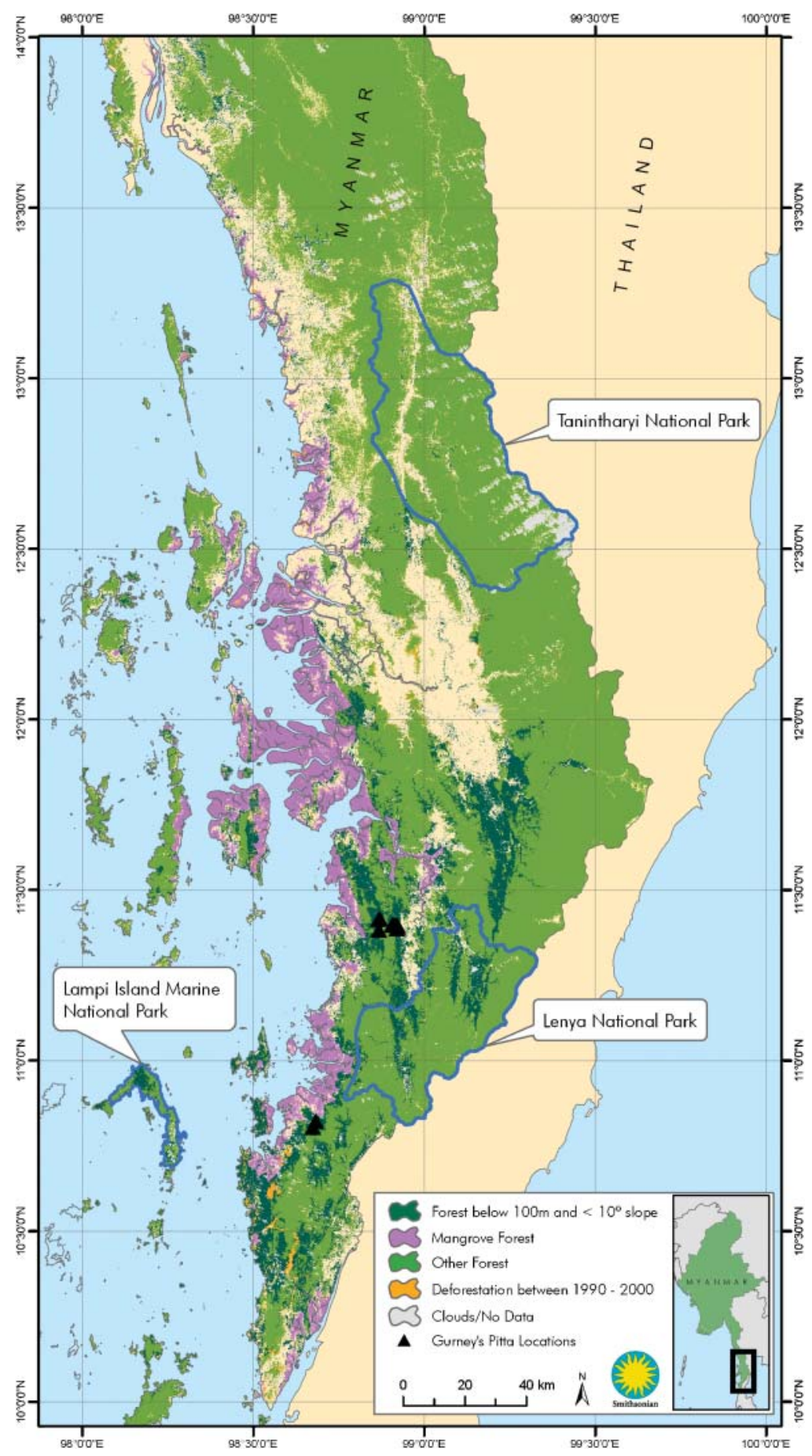

Figure 2. Remaining forest habitat in southern Tanintharyi Division. 
Table 2. Summary of results.

\begin{tabular}{lllllll}
\hline Site Transect & Habitat & Dates & $\begin{array}{l}\text { Distance } \\
(\mathrm{km})\end{array}$ & $\begin{array}{l}\text { Man- } \\
\text { hours }\end{array}$ & $\begin{array}{l}\text { Gurney's } \\
\text { Pitta } \\
\text { contacts }\end{array}$ & $\begin{array}{l}\text { Area } \\
\text { surveyed } \\
\left(\mathrm{km}^{2}\right)\end{array}$ \\
\hline
\end{tabular}

Site 1: 7.5 Mile Camp, Yuzana Plantation \# $1\left(10^{\circ} 26^{\prime} 25.5^{\prime \prime} \mathrm{N} 98^{\circ} 34^{\prime} 59.5^{\prime \prime} \mathrm{E}\right)$

\begin{tabular}{|c|c|c|c|c|c|}
\hline A & $\begin{array}{l}\text { Logged primary } \\
\text { forest/edge }\end{array}$ & $14 / 05$ & 4 & 16 & $\mathrm{o}$ \\
\hline $\mathrm{B}$ & Logged primary forest & $15 / 05$ & 3 & 10 & $\mathrm{O}$ \\
\hline $\mathrm{C}$ & Logged primary forest & $15 / 05$ & 3 & 6 & $\mathrm{o}$ \\
\hline $\mathrm{D}$ & Logged primary forest & $15 / 05$ & 3 & 6 & $\mathrm{O}$ \\
\hline
\end{tabular}

Site 2: 88 Mile Camp, Yuzana Plantation \# 3 ( $10^{\circ} 49^{\prime} \mathrm{O}^{\prime \prime} \mathrm{N} 98^{\circ} 39^{\prime} 79^{\prime \prime} \mathrm{E}$ )

$\begin{array}{lllllll}\text { A } & \text { Logged primary forest } & 17 / 05 & 6 & 28.5 & 2 \text { (1M, IF) } & 6 \\ \text { A (part) } & \text { Logged primary forest } & \begin{array}{l}1805, \\ \text { 180 }\end{array} & 3 & 20 & 3 \text { pairs } & \\ & & 20 / 05 & & & (3 \mathrm{~m} \mathrm{H}) & \\ \text { B } & \text { Logged primary forest } & 18 / 05 & 2 & 8 & 0 & 1 \\ \text { C } & \text { Logged primary forest } & 19 / 05 & 10 & 28 & 1 \text { pair } & 5 \\ \text { D } & \text { Logged primary forest } & 20 / 05 & 4 & 15 & 0 & 1\end{array}$

Site 3: near 123 Mile Camp, Yuzana Plantation \# 2 ( $\left.11^{\circ} 23^{\prime} 59^{\prime \prime} \mathrm{N} 98^{\circ} 55^{\prime} \mathrm{O} 4.9^{\prime \prime} \mathrm{E}\right)$
A
Primary and logged
21/05,
10
40
12 pairs
6

Site 4: near 123 Mile Camp, Yuzana Plantation \# 2 ( $\left.11^{\circ} 24^{\prime} 531^{\prime \prime} \mathrm{N} 98^{\circ} 51^{\prime} 56.8^{\prime \prime} \mathrm{E}\right)$

$\begin{array}{llllll}\text { A } & \text { Logged primary forest } & 23 / 05 & 5 & 32 & 1 \text { pair, + IM } 4\end{array}$

Site 5: near 123 Mile Camp, Yuzana Plantation \# 2 ( $\left.11^{\circ} 23^{\prime} \mathrm{Oo}^{\prime \prime} \mathrm{N} 98^{\circ} 57^{\prime} \mathrm{O} 4 \cdot 9^{\prime \prime} \mathrm{E}\right)$

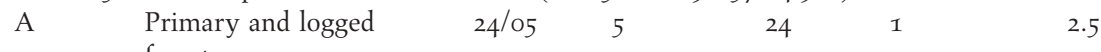
forest

larger trees. The diameter at breast height $(\mathrm{DBH})$ in a random sample of to trees measured 80, 100, 250, 75, 230, 120, 40, 86, 50 and $150 \mathrm{~mm}$. Wild durian Durio sp. was common. Epiphytes were not conspicuous and there were a few lianas. A climbing rattan palm Daemonorops or Calamus sp. was common (Figure 4). It was difficult to determine whether this forest was secondary or primary, on account of the size and density of bamboo and relative absence of large trees. However, it was finally judged to be logged primary forest. Forest understorey supported extensive and sometimes dense tracts of bamboo, especially on the slopes, and Licuala sp. and very large Salacca sp. palms in flatter areas (Figure 4). Ground cover was variously estimated to be $20 \%$ to $60 \%$. A c. $4 \mathrm{~m}$ wide stream meandered through the site. In several areas the ground was waterlogged and covered in aerial roots of unknown tree species. There were several very heavy thunderstorms during the morning of 17 May. A female Gurney's Pitta was heard "skewing" at $13 \mathrm{~h} 45$ and continued calling periodically until 15 hoo. This individual was flushed once off the forest floor and later seen hopping under bamboo. A male was heard giving the "lilip" call at 15 hoo but was not seen. The Gurney's Pittas were observed in an area with numerous Licuala sp. and Salacca sp. palms, numerous small trees and rather little bamboo.

We all returned to the first Gurney's Pitta contact point at $06 h_{30}$ on 18 May and remained here until 11 h3o. Up to three male Gurney's Pittas were heard giving the "lilip" call from ophoo. Calling was recorded from the ground and a horizontal bamboo stem $2 \mathrm{~m}$ above the ground on a slope. During the course of the morning 


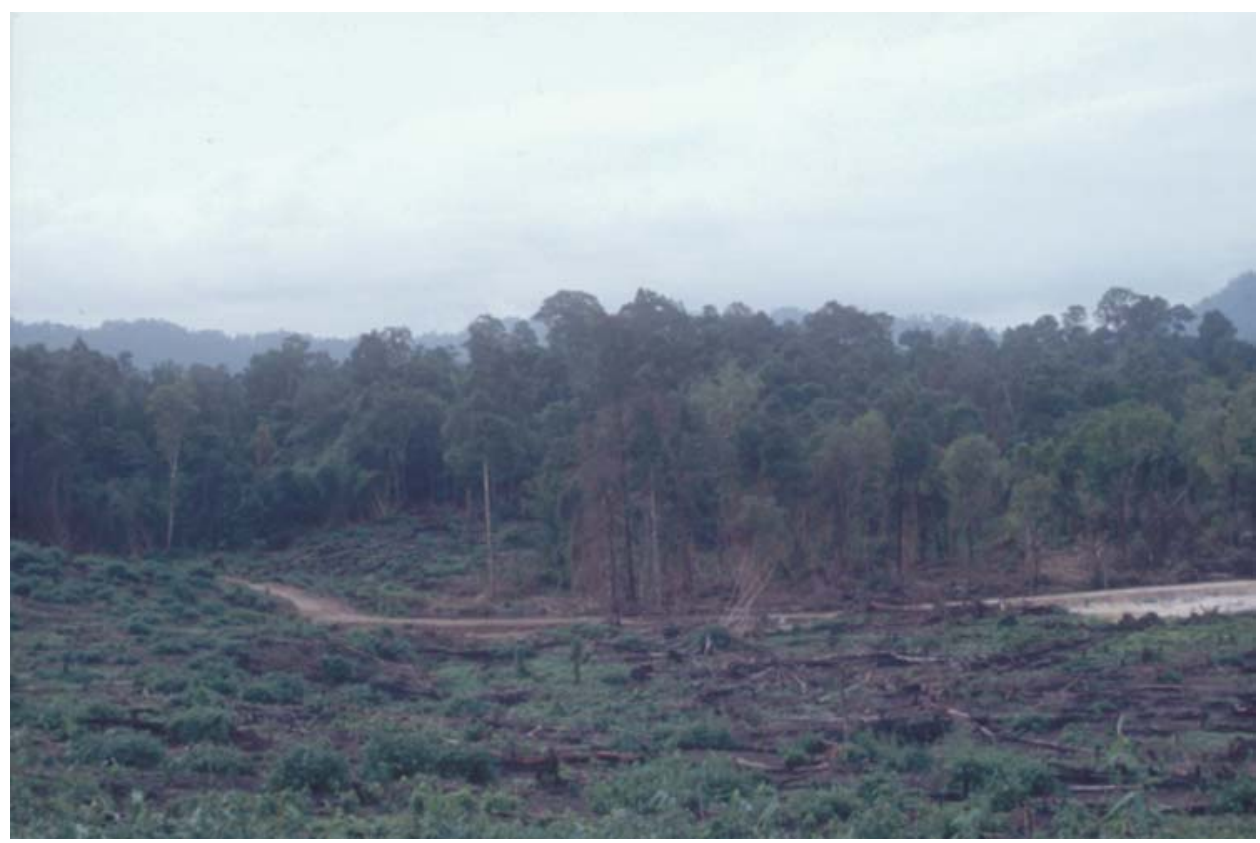

Figure 3. Forest edge near 88 Mile Camp. The area in the foreground has already been cleared and awaits planting with oil palm. (Photograph: J. C. Eames.)

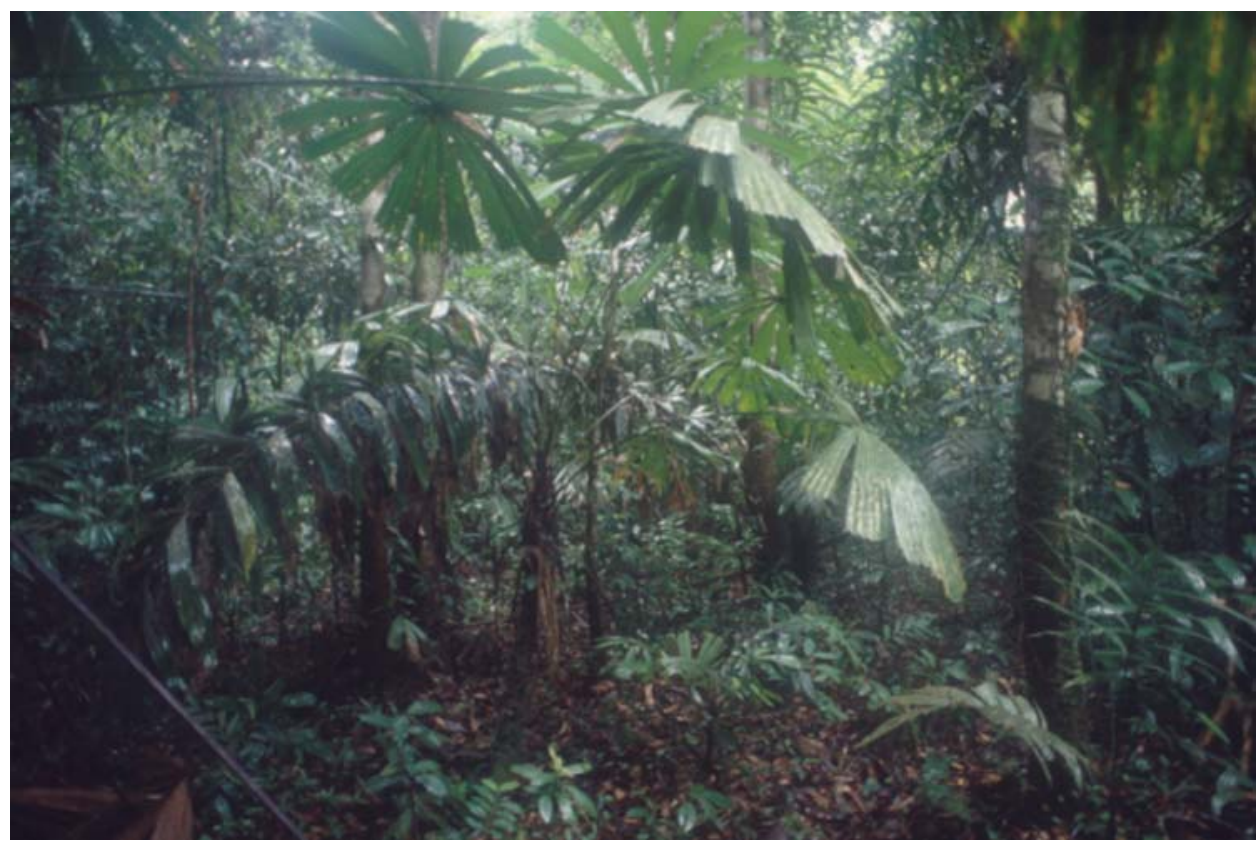

Figure 4. Forest interior near 88 Mile Camp. Both Licuala and Salacca palms are clearly visible. (Photograph: J. C. Eames.) 
all observers had multiple encounters with male and female birds, and we estimate there were up to three pairs in a 2.5 ha area. Later that morning, J.C.E. observed male birds chasing one another, perhaps in a territorial dispute. On 20 May J.C.E. and a guide returned to this location and recorded a Gurney's Pitta giving a single "skew" call at 1oho2 and then two "skews" at 10h50.

Transect $B$ : Transect $\mathrm{B}\left(10^{\circ} 49^{\prime} 35.8^{\prime \prime} \mathrm{N} 98^{\circ} 40^{\prime} 27^{\prime \prime} \mathrm{E}\right)$ was surveyed between 16 hoo and 18 hoo on 18 May by J.C.E., H.H., S.M.A. and S.M. It comprised a nearby discontinuous forest patch some $1 \mathrm{~km}$ distant from transect $\mathrm{A}$, on the west of the road, which was connected to mangroves. Habitat, especially the forest understorey, was similar to that of transect A but no Gurney's Pittas were encountered.

Transect C: Transect C $\left(10^{\circ} 48^{\prime} 18^{\prime \prime} \mathrm{N} 98^{\circ} 40^{\prime} 26.7^{\prime \prime} \mathrm{E}\right)$ was surveyed between o7h1o and 14 hoo on 19 May by J.C.E., H.H., S.M.A. and S.M. Vegetation consisted mainly of large bamboo and there were few large trees. There was rain at $10 h_{30}$ and heavy continuous rain between 11 h3o and 14 hoo. At $c$. oghoo we entered an open, flatter area with more stratified forest structure. Licuala sp. and Salacca sp. palms were evident in the understorey. At oghıo a Gurney's Pitta gave a single "skew". There were a further two "skews" given at 1oh15. Again a single "skew" was heard at 1oh40. At I1 ho5 a male Gurney's Pitta gave the "lilip" call five times. We believe no more than two birds, and probably a pair, were involved.

Transect D: Transect D ( $\left.10^{\circ} 45^{\prime} 49.1^{\prime \prime} \mathrm{N} 98^{\circ} 36^{\prime}{ }_{56.1}{ }^{\prime \prime} \mathrm{E}\right)$ was surveyed between o7hoo and 12 hoo on 20 May by H.H., S.M.A. and S.M. Gurney's Pitta was not recorded but an active nest of Blue-winged Pitta Pitta moluccensis with three eggs was found and photographed.

Site 3: near 123 Mile Camp, Yuzana Plantation \# 2 ( II $^{\circ} 23^{\prime} 59^{\prime \prime} \mathrm{N} 98^{\circ} 55^{\prime} \mathrm{O} 4 \cdot 9^{\prime \prime} \mathrm{E}$ )

Transect A ( $\left.11^{\circ} 23^{\prime} 52.1^{\prime \prime} \mathrm{N} 98^{\circ} 55^{\prime} 08.4^{\prime \prime} \mathrm{E}\right)$ was visited briefly just before dusk on 21 May and then from o6h3o to c.17hoo on 22 May (Figure 5a). Shortly before dusk on 21 May H.H. and S.M.A. heard two Gurney's Pittas calling. Near this point on 22 May at o6h40, one or more Gurney's Pittas gave two "skew" calls and a "lilip" within $5 \mathrm{~m}$ of the forest edge. The male was seen briefly perched on a partially horizontal bamboo c. $1.5 \mathrm{~m}$ off the ground. At o6h50 a male Gurney's Pitta gave the "lilip" call four times. At oghoo, at $19 \mathrm{~m}$ a.s.l., a Gurney's Pitta gave three "skew" calls at $11^{\circ} 23^{\prime} 59.7^{\prime \prime} \mathrm{N} 98^{\circ} 54^{\prime} 25^{\prime \prime} \mathrm{E}$. Nearby between oghoo and ogh4o three different male Gurney's Pittas were frequently calling, whilst an unsexed fourth bird (probably a female) repeatedly "skewed". This bout of calling coincided with a period of sunshine between brief, but heavy showers. These Gurney's Pittas were calling 10-100 $\mathrm{m}$ from the forest edge. At $10 h 50$ at $11^{\circ} 23^{\prime} 53 \cdot 3^{\prime \prime} \mathrm{N} 98^{\circ} 54^{\prime} 38.2^{\prime \prime} \mathrm{E}$, a male Gurney's Pitta was seen and heard giving the "lilip" call. A female was seen standing motionless nearby under a shrub at this location and was observed intermittently until IIh2O when there was a heavy shower. Habitat here consisted of dense secondary growth with a canopy height of $12-15 \mathrm{~m}$. The understorey supported numerous tree saplings but Licuala sp. and Salacca sp. palms were generally absent. At 12 ho5 at $11^{\circ} 23^{\prime} 51.5^{\prime \prime} \mathrm{N} 98^{\circ} 54^{\prime} 47 \cdot 3^{\prime \prime} \mathrm{E}$, a male Gurney's Pitta gave the "lilip" call twice. Later, at 12h26, two males were heard giving the "lilip" call; a third bird gave a single "skew." At 14h45, at 43 m a.s.l., at $11^{\circ} 23^{\prime} 16.5^{\prime \prime} \mathrm{N} 98^{\circ} 55^{\prime} 10.2^{\prime \prime} \mathrm{E}$, a male Gurney's Pitta was seen and heard giving the "lilip" call. A second bird, presumably a female, was heard giving the shortened 


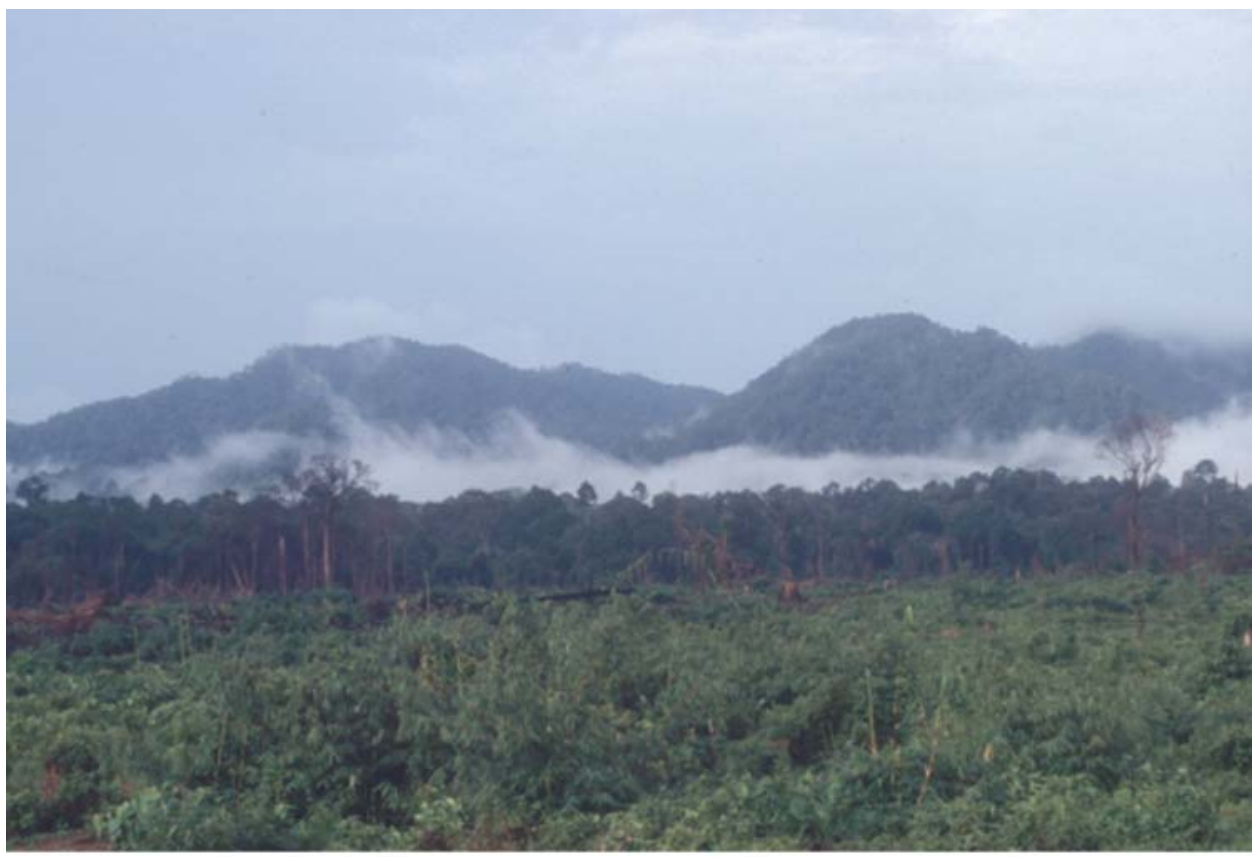

(a)

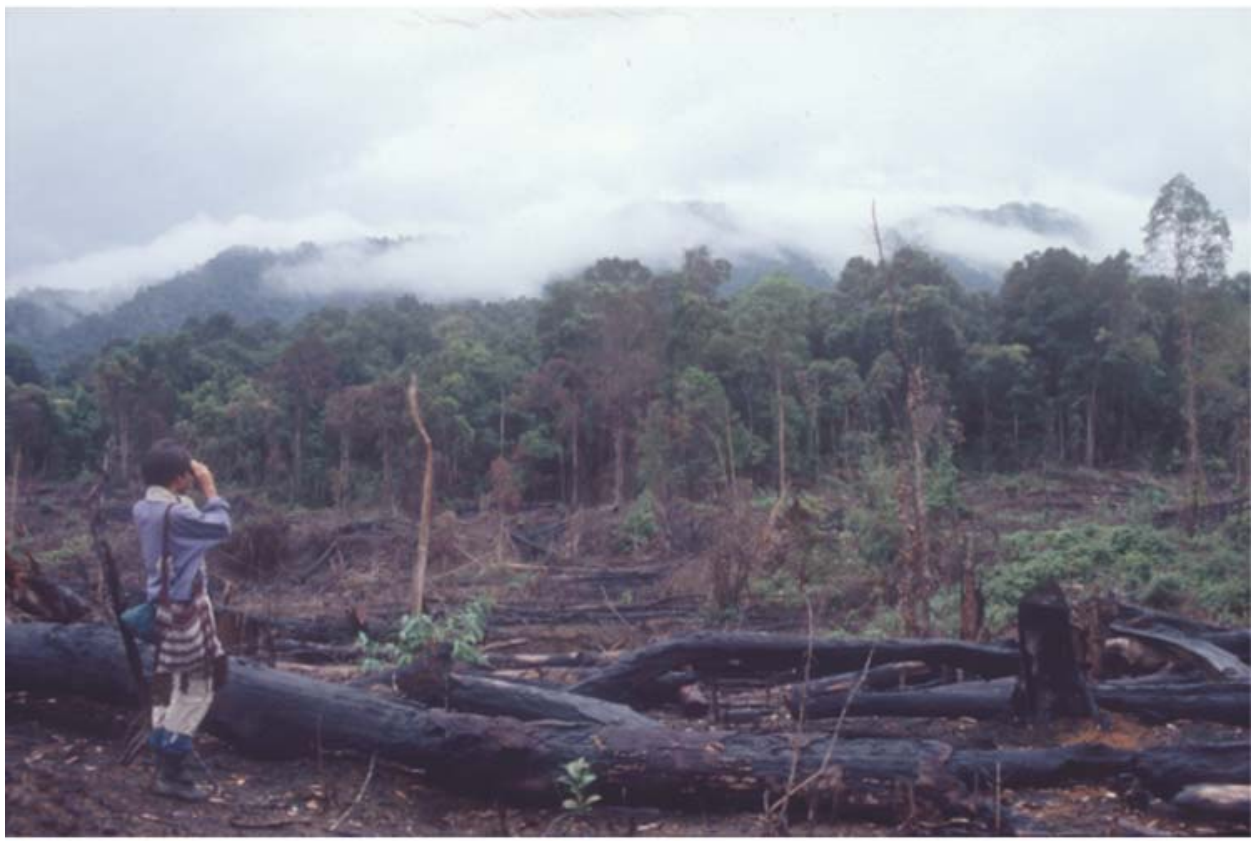

(b)

Figure 5a, b. Two views of forest near 123 Mile Camp. Gurney's Pitta was present at both sites. (Photographs: J. C. Eames.) 
"lilip". Numerous "skew" calls were heard at this point. Habitat here consisted of dense secondary forest, with $80 \%$ canopy cover, much bamboo and dense undergrowth, with many fallen logs. We estimate that we recorded up to 12 pairs of Gurney's Pitta at this site.

Site 4: near 123 Mile Camp, Yuzana Plantation \# 2 ( $\left.\mathrm{II}^{\circ} 24^{\prime} 53 \cdot \mathrm{I}^{\prime \prime} \mathrm{N} 98^{\circ} 5 \mathrm{I}^{\prime} 56.8^{\prime \prime} \mathrm{E}\right) 36$ $\mathrm{m}$ a.s.l. (Figure $5 \mathrm{~b}$ )

Transect $\mathrm{A}\left(\mathrm{II}^{\circ} 24^{\prime} 53 \cdot \mathrm{I}^{\prime \prime} \mathrm{N} 98^{\circ} 5 \mathrm{I}^{\prime} 56.8^{\prime \prime} \mathrm{E}\right)$ was surveyed on 23 May from o7h53 to I6hoo by J.C.E., H.H., S.M.A. and S.M. There were heavy showers mid-morning and again between 14 h3o and 16hoo. A pair of Gurney's Pittas was located at o8hio and gave prolonged views down to $10 \mathrm{~m}$. We suspected they had a nest in the vicinity but despite searching we failed to locate one. The female was heard giving the short "lilip" call and skewing. The male was observed giving the "lilip" call. This male was also observed carrying nesting material, probably a rootlet. This pair was observed $<150 \mathrm{~m}$ from the forest edge. At 10 h5o at $38 \mathrm{~m}$ a.s.l. ( $11^{\circ} 25^{\prime} \mathrm{O}_{3} \cdot 9^{\prime \prime} \mathrm{N} 98^{\circ} 52^{\prime} 12.4^{\prime \prime} \mathrm{E}$ ) a male was heard giving the "lilip" call and seen well. At this point the forest was primary with emergent trees $>50 \mathrm{~m}$ tall.

Site 5: near 123 Mile Camp, Yuzana Plantation \# 2 ( $\left.11^{\circ} 23^{\prime} \mathrm{OO}^{\prime \prime} \mathrm{N} 98^{\circ} 52^{\prime} \mathrm{O} 4 \cdot 9^{\prime \prime} \mathrm{E}\right)$ $38 \mathrm{~m}$ a.s.l.

Transect $\mathrm{A}\left(11^{\circ} 23^{\prime} 12.5^{\prime \prime} \mathrm{N} 98^{\circ} 52^{\prime} \mathrm{O} 6.8^{\prime \prime} \mathrm{E}\right)$ was a $5 \mathrm{~km}$ transect conducted from o8h55 to c. 14 hoo on 24 May by J.C.E., H.H., S.M.A. and S.M. There was heavy, almost continuous rain from shortly after entering the forest, with little bird activity, and the survey was abandoned by 14hoo. At ogho5 a Gurney's Pitta gave the "skew" call twice, perhaps $100 \mathrm{~m}$ from the trail. This transect was along a disused logging road. The forest had extensive bamboo, but in other respects appeared similar to other sites. The topography of the forest was undulating rather than flat.

\section{Remaining forest cover}

Our remote sensing analysis of Landsat satellite imagery between $7^{\circ} \mathrm{N}$ and $14^{\circ} \mathrm{N}$ shows that a few large patches of lowland forest habitat remain south of $12^{\circ} \mathrm{N}$ in Tanintharyi Division. Figure 2 shows remaining Gurney's Pitta habitat south of $12^{\circ} \mathrm{N}$, whilst Figure 6 describes the location of the five largest remaining forest patches at the southernmost tip of Tanintharyi. Here, the total area of lowland rainforest below $100 \mathrm{~m}$ a.s.l. is approximately $4,705 \mathrm{~km}^{2}$, with about $3,496 \mathrm{~km}^{2}$ in flat areas with slopes of less than $10^{\circ}$.

Only $9 \%$ of the remaining lowland forest and only $9 \%$ of the remaining flat areas in lowland forests are contained in the current existing or proposed protected areas of southern Tanintharyi (Table 3). The proposed Lenya National Park has the greatest potential to provide protection to the remaining Gurney's Pitta population (Figure 2). Most of the remaining lowland forest is restricted to small and fragmented patches of less than $\mathrm{I} \mathrm{km}$. Exclusion of these smaller patches reduces the number of lowland forest patches from over 55,000 to 231. The remaining lowland forest patches comprise 205 patches between $I$ and $10 \mathrm{~km}^{2}, 21$ patches between 10 and $100 \mathrm{~km}^{2}$, and 5 patches $>100 \mathrm{~km}^{2}$, giving a total area of $2,558 \mathrm{~km}^{2}$. The five largest patches have a total area of $1,431 \mathrm{~km}^{2}$ and range in size from 137 to $467 \mathrm{~km}^{2}$ (Figure 6). 


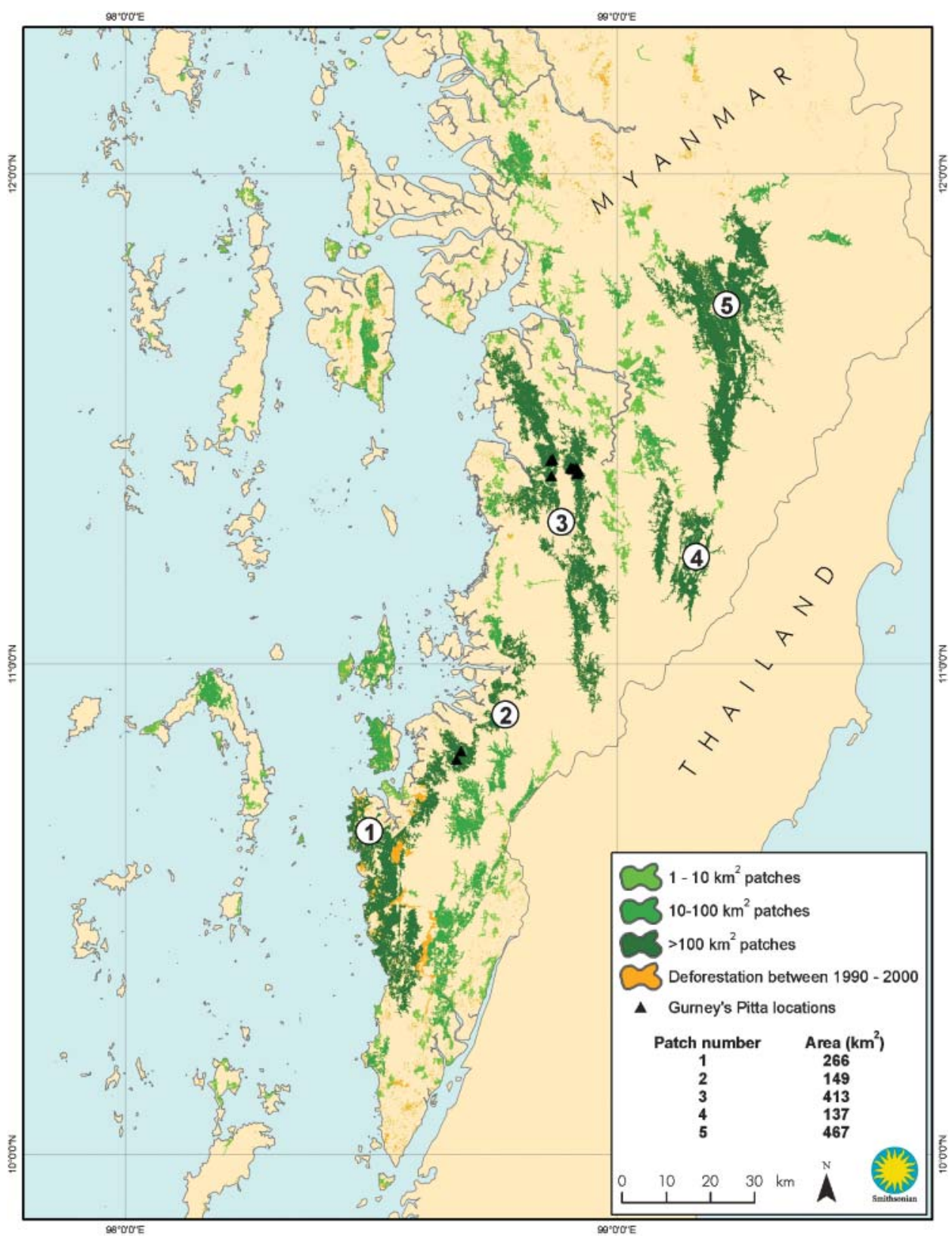

Figure 6. The five largest remaining lowland rainforest patches in southern Tanintharyi Division.

During the survey we drove $285 \mathrm{~km}$ north from Kawthaung along the transTanintharyi highway as far as 123 Mile Camp, Yuzana Plantation \# 2, a point only c. $20 \mathrm{~km}$ west of Lenya (Figure 1). Along the road we encountered numerous oil palm estates, most of which were either newly established or in the process of 
Table 3. Protection status of remaining Gurney's Pitta habitat in southern Tanintharyi Division, Myanmar.

\begin{tabular}{llc}
\hline Protected area & \multicolumn{2}{l}{ Lowland forest $\left(\mathrm{km}^{2}\right)$} \\
\cline { 2 - 3 } & $<100 \mathrm{~m}$ a.s.l. & $<100 \mathrm{~m}$ a.s.l. and $<10^{\circ}$ slope \\
\hline Tanintharyi National Park & 67 & 34 \\
Lenya National Park & 366 & 293 \\
Total & 433 & 327 \\
\hline
\end{tabular}

establishment. Few of the trees observed from the roadside appeared more than 5 years old. All the plantations visited were being established on land supporting logged lowland forest. In many places logged lowland forest still extends to the roadside (Figure 7), although the topography may be too undulating to support Gurney's Pitta. For example from $10^{\circ} 52^{\prime} 40.7^{\prime \prime} \mathrm{N} 98^{\circ} 44^{\prime} 23.4^{\prime \prime} \mathrm{E}$ to $10^{\circ} 54^{\prime} 52^{\prime \prime} \mathrm{N} 98^{\circ} 45^{\prime} 16.5^{\prime \prime} \mathrm{E}$ logged lowland forest was continuous along the roadside. From $10^{\circ} 52^{\prime} 40.7^{\prime \prime} \mathrm{N} 98^{\circ} 44^{\prime} 23.4^{\prime \prime} \mathrm{E}$ to $11^{\circ} \mathrm{O}^{\prime} 28.3^{\prime \prime} \mathrm{N} 98^{\circ} 45^{\prime} 49 \cdot 6^{\prime \prime} \mathrm{E}$ logged lowland forest was virtually continuous to the roadside, with only occasional cleared areas and very small human settlements. Elevation along this stretch of road was in the range $0-5 \mathrm{~m}$ a.s.l. At all five survey locations there was evidence of recent forest clearance, although little active clearance was evident, probably because the rainy season had already begun. In places it was clear that there had been considerable burning in the previous dry season. At all five locations commercial oil palm plantations were being planted-out. Some tree clearing was still occurring at 7 I/2 Mile Camp, Yuzana Plantation \# 2 was well established and Yuzana Camp \# 3 was still under construction.

Deforestation is concentrated in the southern lowland areas within the study region and has now reached dramatic levels. For example, one of the largest contiguous lowland forest patches in the south was fragmented during the last decade and had local deforestation rates of $1.0 \%$ annually, dramatically higher than the global average of $0.2 \%$ (FAO 2002; Figure 8). In 1990 the patch was $423 \mathrm{~km}^{2}$ and by 2000 it had been reduced by $37 \%$ to $265 \mathrm{~km}^{2}$.

Based on data provided in Gretton et al. (1993), a density estimate of 3.6-6 pairs of Gurney's Pitta per $\mathrm{km}^{2}$ of suitable habitat was suggested by BirdLife International (2001), although it has been suggested that lack of suitable habitat may have led to artificially high densities at this site (Uthai Treesucon in litt. 1o January 2004). It has also been pointed out that the species is absent from apparently suitable habitat (Paul Donald in litt. 9 January 2004). Nonetheless, based on these density estimates, the five largest remaining forest patches in Myanmar, covering $1,431 \mathrm{~km}^{2}$, could support Gurney's Pitta populations with 5,152-8,586 pairs. The smallest of these forest patches covering $137 \mathrm{~km}^{2}$ could support a population of Gurney's Pitta in the range of 493-822 pairs. The largest forest patch, covering $467 \mathrm{~km}^{2}$, could support a population in the range $1,681-2,802$ pairs (Figure 6). These estimates are strengthened by the fact that our survey found the species within the same basic habitat parameters as previously reported for Thailand (i.e. below $100 \mathrm{~m}$ a.s.l. and slopes of $<10^{\circ}$ ), although it does not mean that in Myanmar they are confined to them.

\section{Discussion}

This survey rediscovered Gurney's Pitta in Myanmar. We have established that the species still occurs within its historical range in Myanmar, although it probably no 


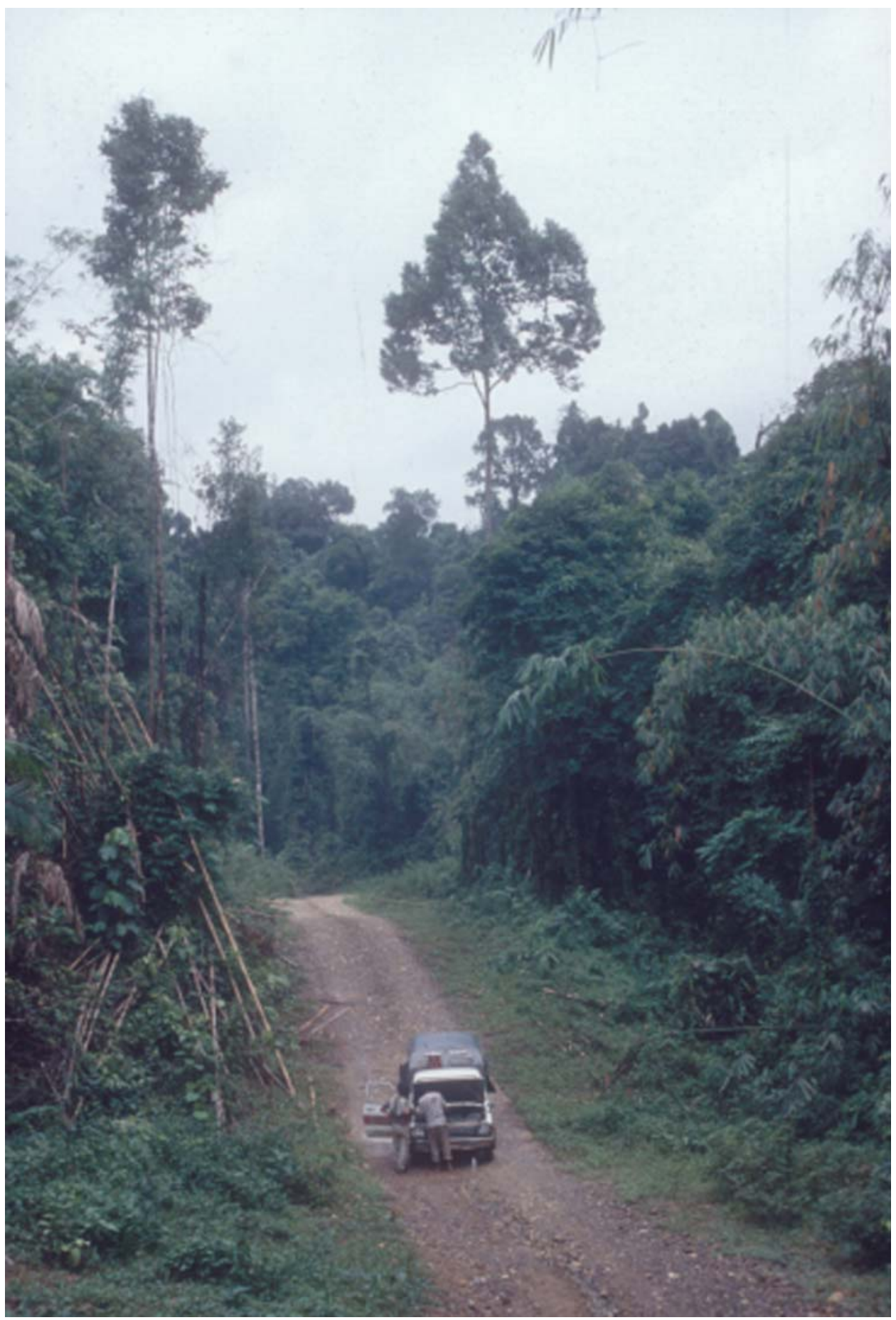

Figure 7. In many areas along the trans-Tanintharyi highway, logged lowland forest reaches the roadside. Note the small size of the road and the absence of traffic. (Photograph: J. C. Eames.) 


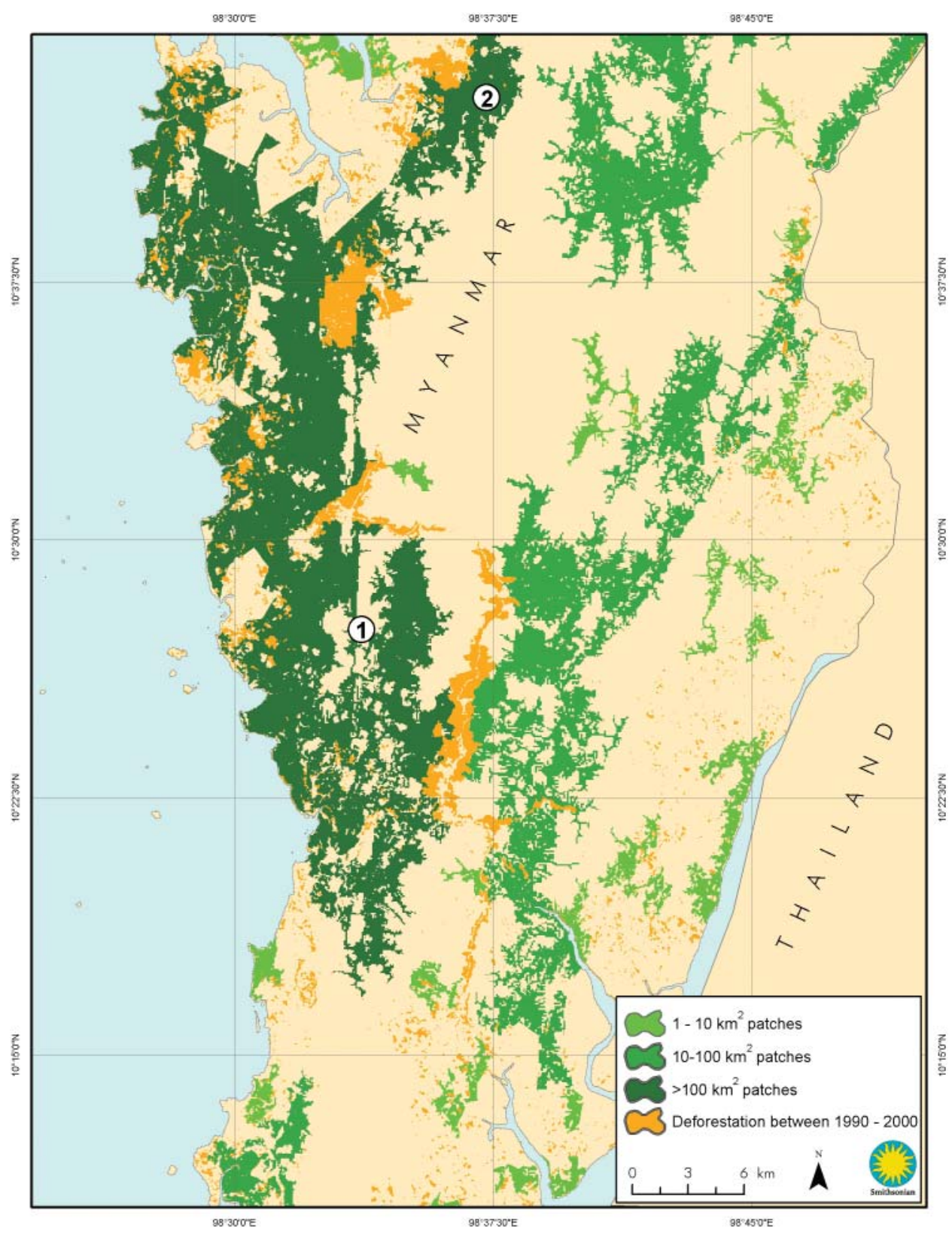

Figure 8. Forest patch size and deforestation between 1990 and 2000.

longer occurs at all its historical collecting localities. Responses by calling birds to playback invariably occurred within $5 \mathrm{~min}$. We therefore consider it unlikely that we double-counted birds. Our results demonstrate that the global population of Gurney's Pitta is at least double the latest published estimate of 11 pairs (BirdLife International 2001) and probably far greater. Site 3, near 123 Mile Camp, supports a population 
greater than Khao Pra-Bang Khram Pra-Bang Khram Wildlife Sanctuary in Thailand. The lack of road infrastructure in southern Tanintharyi Division, the heavy rainfall and the short duration of the survey prevented exploration of forest areas beyond $2 \mathrm{~km}$ from the roadside. We estimate that the maximum area covered by the survey was $30 \mathrm{~km}^{2}$. As the results of our GIS analysis indicate that the total area of remaining lowland rainforest south of $14^{\circ} \mathrm{N}$, below $100 \mathrm{~m}$ a.s.l. is approximately $4,705 \mathrm{~km}^{2}$, with about $3,496 \mathrm{~km}^{2}$ in flat area with slopes of less than $10^{\circ}$, we estimate that we surveyed less than $1 \%$ of all remaining potentially suitable Gurney's Pitta habitat (Figures 2, 6).

Our simple extrapolations indicate that Gurney's Pitta populations within its historical range in Myanmar could be two orders of magnitude greater than the previously published global population figure. Clearly the survey of these largest remaining forest blocks to determine actual population density of Gurney's Pitta is a major priority (Figure 6). A reassessment of the conservation status of the species is also now appropriate.

In deriving the above estimates we have been conservative in considering only the largest remaining forest blocks within the historical range of the species in Myanmar based on known ecological parameters. If, however, the species does not occupy all apparently suitable habitat then these estimates may be very high. There are a number of additional variables, including habitat, climate, ecology, rate of forest loss and status of protected areas that must be further considered before a clear picture of the overall status of Gurney's Pitta and the prospects for its conservation in Myanmar can be fully determined. The northward dispersal of endemic species in peninsular Thailand (including Malaysia and Myanmar) is limited by the distribution of rainforest. The Burmese side of the peninsula is wetter than the Thai side, and rainforest extends to at least $13^{\circ} \mathrm{N}$ (Medway and Wells 1976). Some authors describe this as true evergreen rainforest, although without the typically Malayan floristic groups, further noting that there is a complex mosaic with semi-evergreen rainforest (Whitmore 1975). Indeed our subjective assessments during this survey would lead us to label the forest as evergreen rather than semi-evergreen. Giant Pitta Pitta caerulea is another lowland forest specialist whose range extends as far north as Mount Nwalabo ( $\left.14^{\circ} \mathrm{O} 2^{\prime} \mathrm{N} 98^{\circ} 28^{\prime} \mathrm{E}\right)$ near Tavoy (Dawei) (Chasen 1939, Smythies 1953). It therefore seems possible that the range of Gurney's Pitta in Myanmar could extend to $14^{\circ} \mathrm{N}$ and this should be considered a priority for research. However, the amount of available habitat declines sharply north of $12^{\circ} \mathrm{N}$. Another consequence of a different rainfall regime is a differing invertebrate biomass. Gurney's Pitta is known to feed almost exclusively on soil invertebrates (BirdLife International 2001), whose populations are determined largely by rainfall. This could mean that Gurney's Pitta could occur at differing densities and have a different breeding regime (i.e. a tendency to be multiple-brooded in one part of the its range) within different parts of its range, though it is unlikely to be migratory anywhere (Round 1995).

Collar et al. (1986) suggested that interspecific competition with Banded Pitta Pitta guajana may limit Gurney's Pitta numbers. The two species occur together in the same habitats in Thailand. With segregation and dominance based on subtle variations in forest-floor conditions, competition for reduced resources on the hill-slope may prevent Gurney's Pitta from extending its vertical range, where Banded Pitta is dominant to the exclusion of the former species. Perhaps the dominance of Banded Pitta in the southern Thai provinces forms a natural barrier defining the southern 
extent of the range of Gurney's Pitta. Like Collar et al. (1986) we can find no record of Banded Pitta from southern Myanmar. However, Chasen (1939) and Lambert and Woodcock (1996) suggested it may occur there. Since Banded Pitta appears on current knowledge to be absent from Tanintharyi, Gurney's Pitta may occupy a wider altitudinal amplitude in that part of its range, and consequently show increased population densities in Myanmar. The other large pitta species that occur in the Tenasserim Range are Giant Pitta and Blue Pitta Pitta cyanea. Giant Pitta is sympatric with Gurney's Pitta in Thailand. Both are large-bodied species and interspecific niche competition seems unlikely.

Ecological and behavioural studies of Gurney's Pitta have inevitably been undertaken at the extant site in Thailand, which lies towards the southern limit of the species' known range. Indeed, of 27 localities given for the species in BirdLife International (2001), only four are further south than Khao Nor Chuchi, and all are clustered immediately to the south. This site could therefore be atypical for the species as a whole. It may not be wise to base conservation prescriptions for the species solely on data obtained from such a site. We therefore strongly recommend a study of the ecology and biology of the species be undertaken at selected sites in Myanmar.

Our anecdotal evidence indicates that virtually all forest clearance is for conversion to oil palm plantations as part of government policy. This conversion has also been documented by others (Aung Than 2002). The government of Myanmar has been developing oil palm plantations in Tanintharyi since 1998. The objective has been to meet a shortfall in domestic edible oil production. The 5-year plan, begun in 1999 involved the establishment of 231,508 ha of oil palm across Tanintharyi Division with 20,534 ha $(9 \%)$ in Dawei District, 56,879 ha (24\%) in Myeik District and 154,095 ha $(67 \%)$ in Kawthaung District. The current land classification of areas in Tanintharyi Division identified for conversion to oil palm is shown in Table 4.

Given the environmental requirements of oil palm, which include rainfall in excess of 2,100 mm per annum and a preference for flat, low-lying areas at or below $75 \mathrm{~m}$ a.s.l., the Myanmar Perennial Crop Enterprise has prioritized such areas and begun conversion of them with zeal. Given the ecological requirements of Gurney's Pitta it would be hard to design a better species extermination plan! Table 4 shows that most of the planned conversion in Myeik and Kawthaung District will be of unclassified and reserved forest. The project is now in its fourth year but financial constraints have meant only 32,400 ha have so far been converted. The project was revised in 2003 and the proposed area for conversion reduced by $40 \%$ to 93,976 ha, whilst the project period has been extended to 2008 (Htin Hla et al. 2003).

Before the switch into oil palm, the previous most widespread land-use in the areas surveyed was commercial logging (Collins et al. 1991, Round 1995, BirdLife

Table 4. Current land classification of areas in Tanintharyi Division for conversion to oil palm (Htin Hla et al. 2003).

\begin{tabular}{llccc}
\hline District & $\begin{array}{l}\text { Wasteland }(<10 \% \\
\text { canopy cover) }(\mathrm{ha})\end{array}$ & Unclassified (ha) & Reserved forest (ha) & $\begin{array}{l}\text { Total ha to } \\
\text { be converted }\end{array}$ \\
\hline Dawei & 8,224 & 1,213 & 11,097 & 20,534 \\
Myeik & 1,306 & 26,535 & 29,038 & 56879 \\
Kawthaung & 1,319 & 129,993 & 22,783 & 154,095 \\
Total & & & 231,508 \\
\hline
\end{tabular}


International 2001). There is evidence that Thai loggers had been logging in Tanintharyi Division even before the 1988 logging ban in Thailand. In Myanmar enforcement was weak and access difficult. However, we found evidence of logging roads reaching historical collecting localities on the coast including Sungeibaleih and Or Gyi. Improvements in the trans-Tanintharyi highway led to increased enforcement by the Myanmar authorities after 1998 and cut logs and heavy machinery was confiscated (Htin Hla et al. 2003). We certainly found evidence at 88 Mile Camp, in the form of abandoned bulldozers (Figure 9). Logging activities and their abandonment resulted in the eventual establishment of large areas of regenerating primary and secondary forest. It has been suggested that Gurney's Pitta may prefer, and may occur at higher densities in, secondary forest (Gretton et al. 1993, Lambert and Woodcock 1996, BirdLife International 2001). It is possible that the actions of Thai loggers may have created and expanded the area of optimal Gurney's Pitta habitat in Tanintharyi. Thus, it is ironic and speculative to consider that in the late 1980s and 1990s when conservation efforts for Gurney's Pitta in Thailand were being intensified, the population in Myanmar was perhaps at its greatest. It is these secondary forests that are now being cleared in the level lowlands of Tanintharyi Division to make way for oil palm.

Human population density in all parts of Tanintharyi visited appeared very low, except around Kawthaung Town. Aside from oil palm plantation facilities and camps, human habitation consisted of widely separated small hamlets and army camps. The only major centre of habitation visited was the small coastal town of Bokepyin $\left(11^{\circ} 14^{\prime} \mathrm{N} 98^{\circ} 45^{\prime} \mathrm{E}\right)$. Because human population density is currently low, human

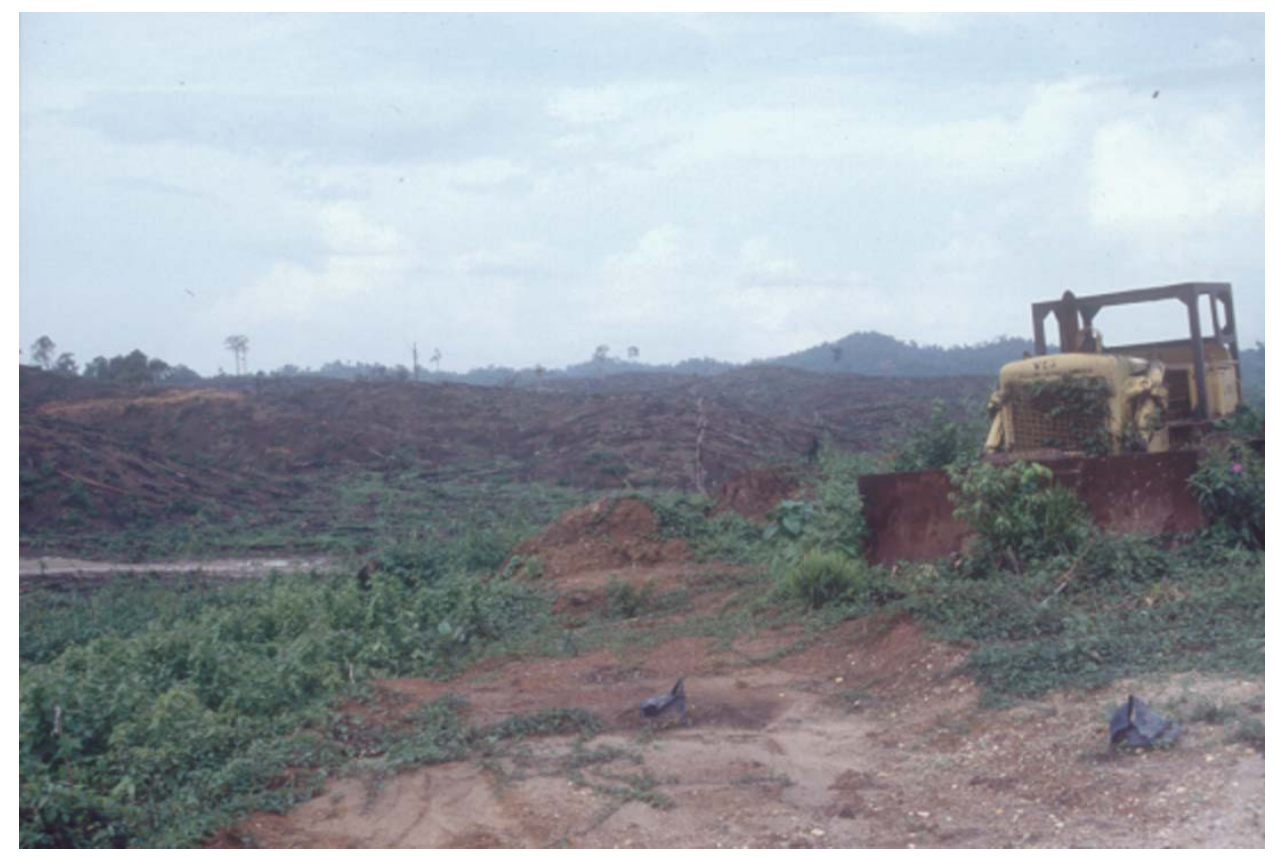

Figure 9. Clearfelled area awaiting planting with oil palm in the vicinity of 88 Mile Camp. An long-abandoned Thai bulldozer is proof of past logging in this area. (Photograph: J. C. Eames.) 
impacts on habitats have been relatively low, and the megafauna remains in situ. This is supported by the results of our survey (Htin Hla et al. 2003) and the work of others (Lynam 2003).

Conflicting evidence exists regarding the status of protected areas in Tenasserim. The only notified protected areas of which we are currently aware are Moscos Islands Wildlife Sanctuary and Lampi Island Marine National Park. We have also learnt of proposals to establish the Lenya National Park $\left(1,766 \mathrm{~km}^{2}\right)$ and the Tanintharyi National Park (2,590 $\left.\mathrm{km}^{2}\right)$ (M. Rao in litt. 22 July 2003). However, this differs slightly from other information received as follows regarding the Tanintharyi Nature Reserve [sic] and Lenya River Wildlife Sanctuary [sic]. These are apparently declared but not gazetted. This means the Forest Department has declared the intention to set up the reserves but they are not officially on the map (A. Lynam in litt. 21 July 2003). The details of proposals provided in Aung Than (2002) on these points are ambiguous. Our GIS analysis indicated there are extensive areas of optimal Gurney's Pitta habitat in Lenya National Park (Figure 2). This needs to be confirmed as a matter of priority.

This survey has shown there is a globally significant population of Gurney's Pitta in southern Tanintharyi Division that is under pressure from forest conversion to oil palm. Contrary to the situation in neighbouring Thailand, sufficient forest remains to establish landscape level protected areas covering a broad ecological continuum embracing offshore islands, coral reefs, inter-tidal mudflats, mangrove, lowland forests and hill evergreen forest. It has also been suggested that a network of smaller lowland forest protected areas nested within oil palm plantations in the context of a stable agricultural landscape may be a desirable option (John Parr in litt. 9 January 2004). Securing populations of Gurney's Pitta within either expanded or entirely new protected areas must be the best chance for the conservation of this species and the Sundaic flora and fauna of which it is part.

Several important questions regarding the ecology and distribution of Gurney's Pitta remain unanswered. For example: Does the species inhabit slopes as well as level lowlands in Myanmar? What defines the northern and southern extent of its range? Does interspecific competition with Banded Pitta in Thailand limit the southern limit of its range and confine Gurney's Pitta to the level lowlands? We strongly recommend the immediate initiation of a study on the ecology and biology of the species at selected sites in Myanmar.

\section{Acknowledgements}

This project was generously supported by the Darwin Initiative as part of the project entitled "Building constituencies for site-based conservation in Myanmar", the Rufford Trust by means of a Rufford Small Grant for Nature Conservation, in association with the Whitley Laing Foundation, the Royal Society for the Protection of Birds (RSPB) and the BirdLife International Asia Bird Fund. We would particularly like to thank Mr Josh Cole of the Rufford Trust and Mr Steve Parr of the RSPB. In Myanmar we would like to thank the Ministry of Travel and Tours for granting us permission; Lt. Col. Kyaw Phyo, Chairman of the District Peace and Development Council, Kawthaung Division; Mr Kin Latt, Manager 7 1/2 Mile Camp, Yuzana Plantation \# 1; Mr The Too, Mr Toe Kyi and Mr Ag Toe of 88 Mile Camp, Yuzana Plantation \# 3; Mr Khin Mg Myint and Mr U Shwe Sein, 123 Mile Camp, Yuzana Plantation \# 2. We would also like to thank U Khine Soe Tha and U Nyunt Hlaing of VES and 


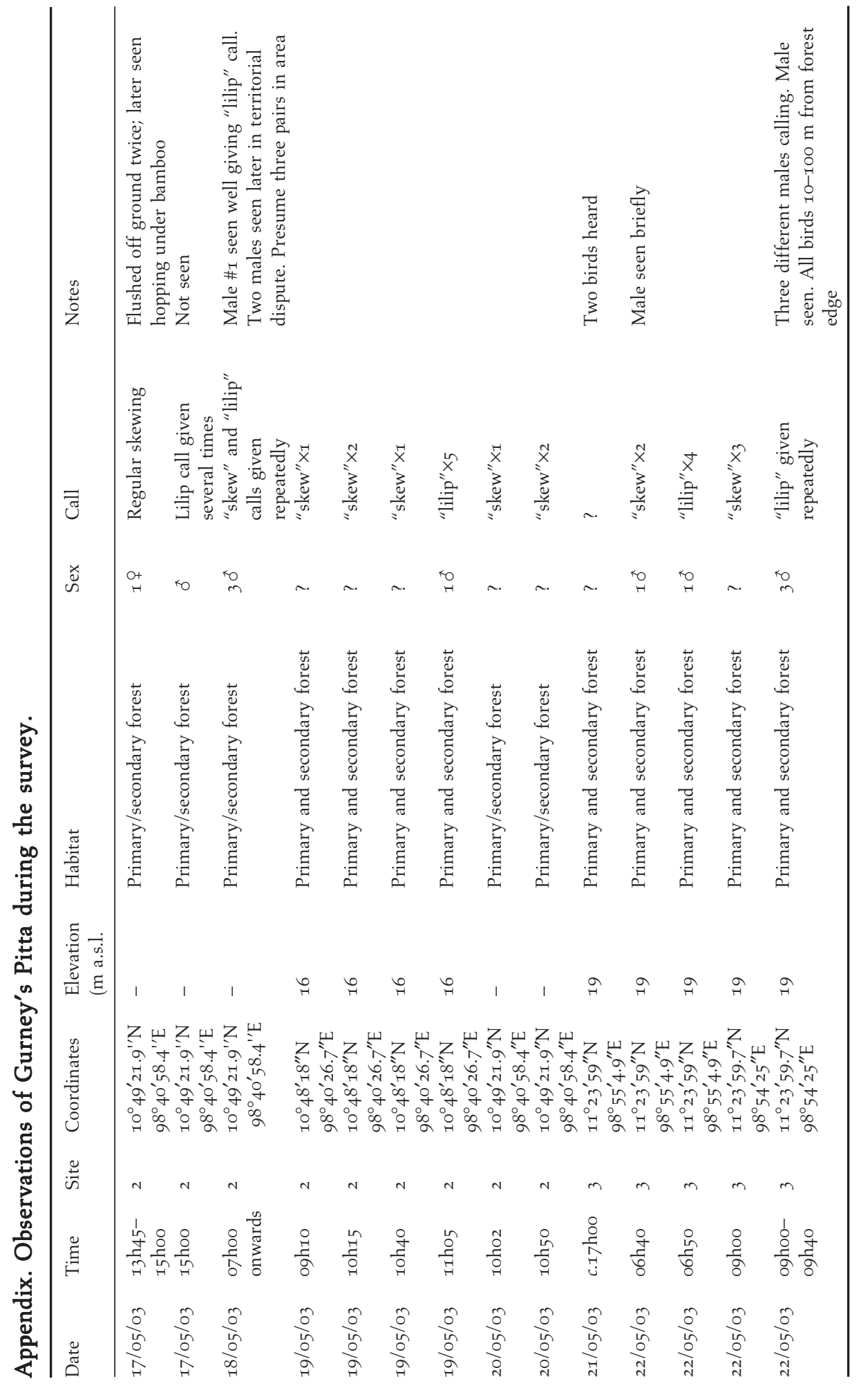




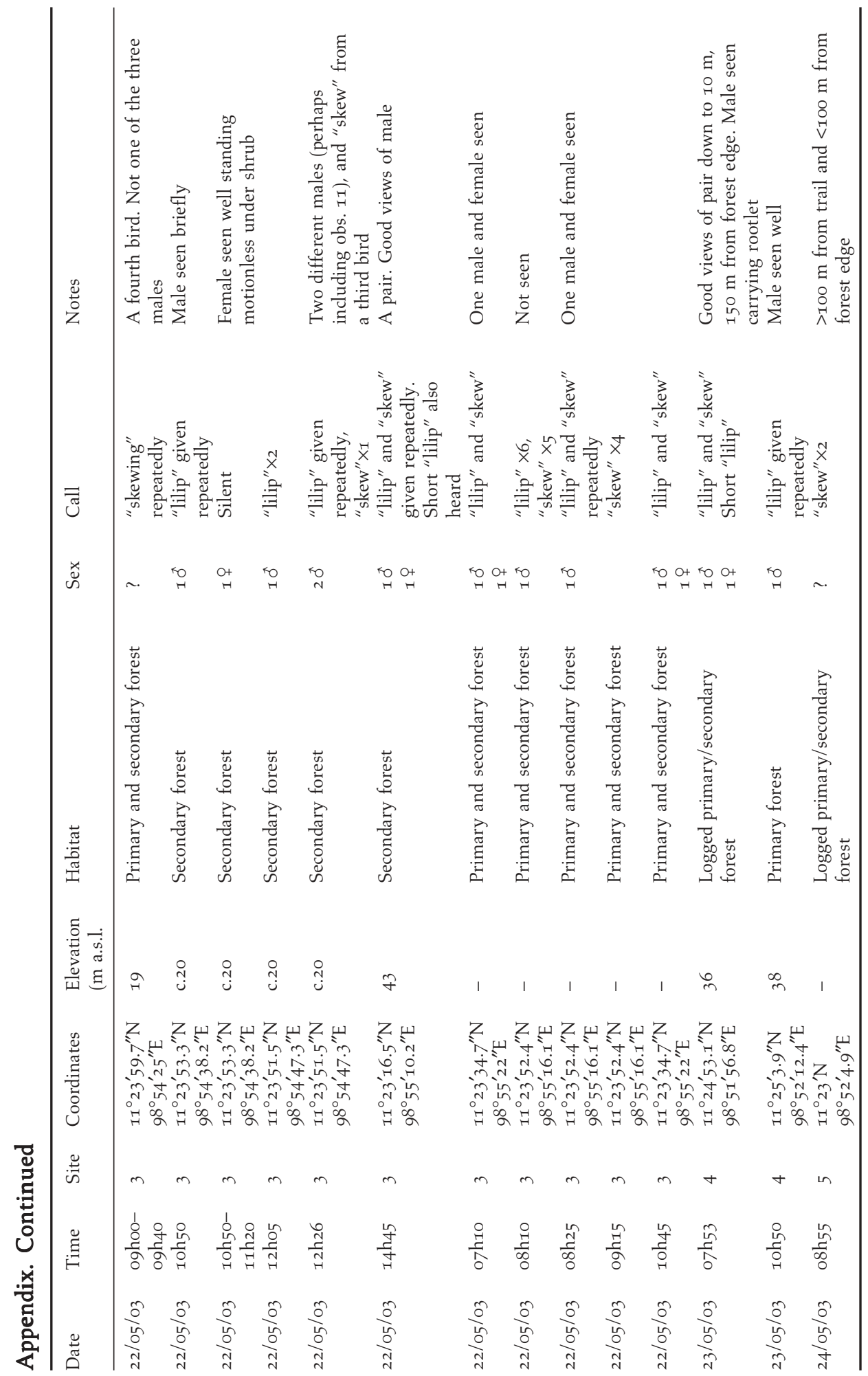


the Andaman Club, and Daw Kyawt Kyawt Lwin, our guides, drivers, drivers' assistants and cook and kitchen staff for all their efforts. We would also like to thank $\mathrm{Mr}$ Philip D. Round and Mr Yothin Meekeow for their efforts in the 2002 attempted survey, and to Phil for providing tapes of the calls of Gurney's Pitta. Thanks also go to Ha Quy Quynh who produced Figure 1. This paper was peer-reviewed by Dr Nicholas Brickle, Dr N. J. Collar, Peter Davidson, Dr Paul Donald, John Parr and Uthai Treesucon.

\section{References}

Aung Than (2002) Report on wildlife reconnaissance trip to Tanintharyi Division: 20 April to 4 May 2002. Unpublished report.

BirdLife International (2001) Threatened birds of Asia: the BirdLife International Red Data Book. Cambridge, U.K.: BirdLife International.

Chasen, F. N. (1939) The Birds of the Malay Peninsula. Volume IV: The birds of the low country, jungle and scrub. London: H. F. and G. Witherby.

Collar, N. J., Round, P. D. and Wells, D. R. (1986) The past and future of Gurney's Pitta. Forktail 1: 29-51.

Collins, N. M., Sayer, J. A. and Whitmore, T. C. (eds.) (1991) The conservation atlas of tropical forests: Asia and the Pacific. London: Macmillan.

FAO (2002) Global forest resource assessment 2000. Main report. Rome: FAO (FAO Forestry Papers 140).

Farr, T.G. and Kobrick, M. (2000) Shuttle Radar Topography Mission produces a wealth of data. Am. Geophys. Union Eos 81: 583-585.

Gretton, A., Kohler, M., Lansdown, R. V., Pankhurst, T. J., Parr, J. and Robson, C. (1993) The status of Gurney's Pitta Pitta gurneyi, 1987-1989. Bird Conserv. Int. 3: 351-367.

Gyldenstolpe, N. (1916) Zoological results of the Swedish Zoological Expedition to Siam 1911-1912 and 1914-1915: Birds. Kungl. Svenska Vet. Akad. Handl. 56(2): 1-160.

Htin Hla, Sein Myo Aung, Saw Moses, Eames, J. C. and Saw Nyunt Tin (2003) Gurney's Pitta survey and biodiversity conservation assessment in Tanintharyi Division, Myanmar. Unpublished report.

Hume, A. O. (1875) A second list of the birds of Tenasserim. Stray Feathers 3: 317-326.

Lambert, F. and Woodcock, M. (1996) Pittas, broadbills and asities. Robertsbridge, East Sussex: Pica Press.

Leimgruber, P., Kelly, D. S., Steininger, M., Brunner, J., Müller, T., and Songer, M. A. (2003) Forest cover change patterns in Myanmar 1990-2000. Report to Conservation International and the U.S. Fish and Wildlife Service.

Lynam, A. J. (2003) A national tiger action plan for the Union of Myanmar. Bangkok: Myanmar Forest Department, Ministry of Forestry, Myanmar and Wildlife Conservation Society, International Program.

Medway, Lord and Wells, D. R. (1976) The birds of the Malay Peninsula. Volume V: Conclusion and survey of every species. London: Witherby.

Round, P. D. (1995) On the seasonality and distribution of Gurney's Pitta Pitta gurneyi. Forktail 11: 155-158.

Round, P. D. and Treesucon, U. (1986) The rediscovery of Gurney's Pitta. Forktail 2: 53-66.

Smythies, B. E. (1953) The birds of Burma. Edinburgh: Oliver and Boyd.

Whitmore, T. C. (1975) Tropical rain forests of the Far East. Oxford: Clarendon Press.

JONATHAN C. EAMES

BirdLife International in Indochina, No. 4, Lane 209, Doi Can Street, Hanoi, Vietnam. (e-mail: Eames@birdlife.netnam.vn) 
HTIN HLA, SEIN MYO AUNG, SAW MOSES, U SAW NYUNT TIN

Wild-bird Adventure Travels and Tours, PO Box 1136, Yangon, Myanmar (e-mail: wildbirdtt@ mptmail.net.mm)

PETER LEIMGRUBER, DANIEL S. KELLY

Smithsonian Institution, National Zoological Park, Conservation and Research Center, 1500 Remount Road, Front Royal,VA 22630,U.S.A. (e-mail: leimgruberp@crc.si.edu, kellyd@ crc.si.edu)

Received 14 May 2004; revision accepted 27 September 2004 